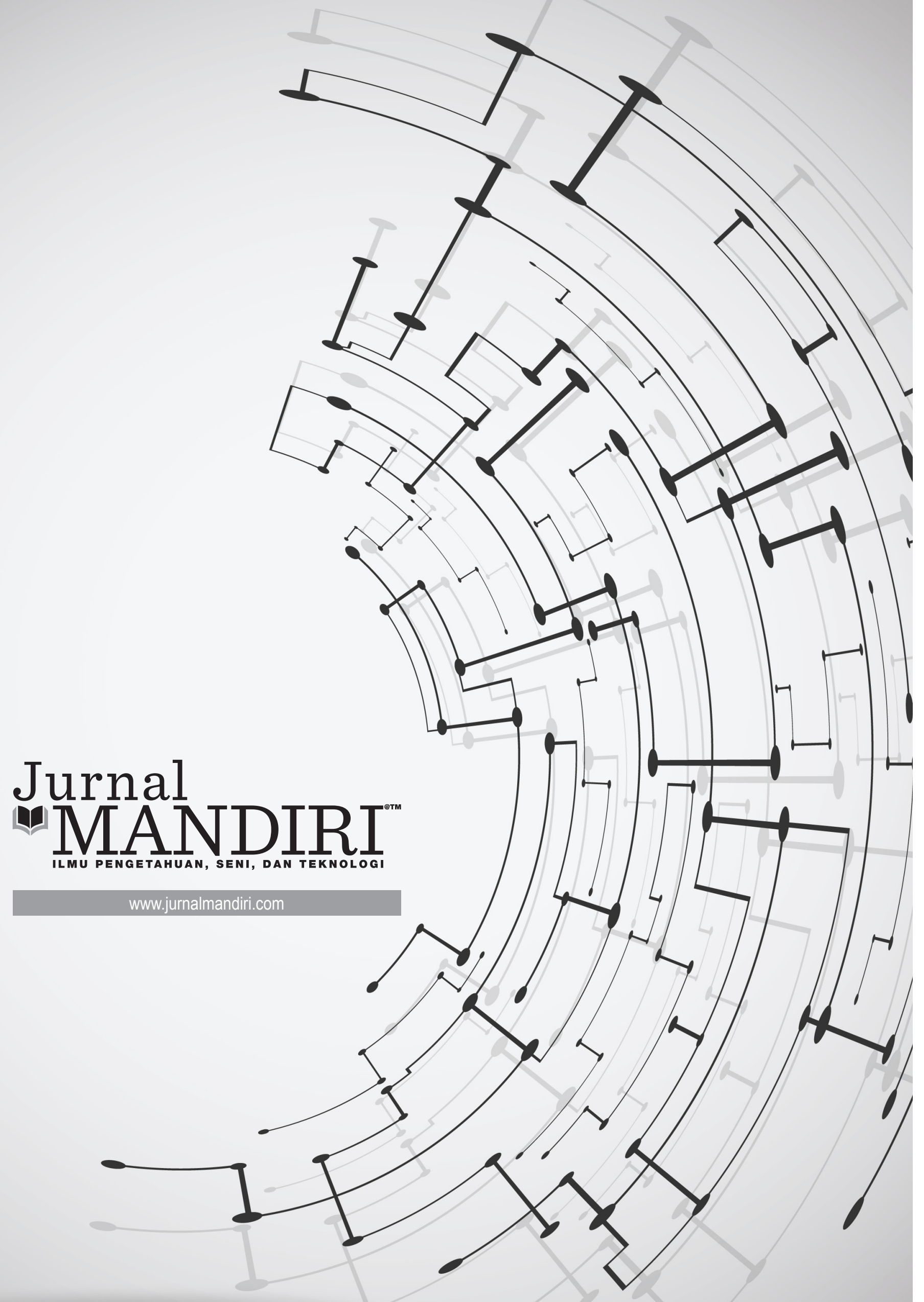


ISSN : 2580-3220, E-ISSN : 2580-4588

J. Mandiri., Vol. 2, No. 2, Desember 2018 (333- 346)

(C)2018 Lembaga Kajian Demokrasi

dan Pemberdayaan Masyarakat (LKD-PM)

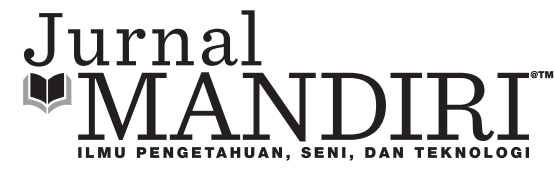

\title{
ANALISIS PENGARUH KEPEMIMPINAN TRANSFORMASIONAL, PROMOSI JABATAN, LINGKUNGAN KERJA NON FISIK TERHADAP KEPUASAN KERJA KARYAWAN PT KUSTODIAN SENTRAL EFEK INDONESIA
}

\author{
I Gede Adi Indrawan \\ Fakultas Ekonomi, Universitas Pamulang \\ gedeadiindrawan@gmail.com
}

\begin{abstract}
Abstrak
Tujuan dari penelitian ini adalah untuk mengetahui dan menganalisis pengaruh kepemimpinan transformasional, promosi jabatan dan lingkungan kerja non fisik terhadap kepuasan kerja karyawan PT Kustodian Sentral Efek Indonesia. Metode penelitian yang digunakan adalah deskriptif dengan pendekatan kualitatif dengan instrumen penelitian berupa wawancara, observasi dan telaah dokumen. Hasil penelitian ini menunjukkan bahwa variabel kepemimpinan transformasional, variabel promosi jabatan dan variabel lingkungan kerja non fisik secara parsial maupun secara simultan memiliki pengaruh positif dan signifikan terhadap kepuasan kerja karyawan PT Kustodian Sentral Efek Indonesia.
\end{abstract}

Kata Kunci: Kepemimpinan transformasional, Promosi Jabatan, Lingkungan Kerja Non Fisik, Kepuasan Kerja Karyawan.

\section{PENDAHULUAN \\ Latar Belakang}

Kepuasan kerja merupakan keadaan emosional yang positif dari seseorang yang ditimbulkan dari penghargaan atas sesuatu pekerjaan yang telah dilakukannya. Kepuasan kerja dikatakan lebih lanjut adalah "merupakan hasil dari persepsi seseorang mengenai seberapa baik pekerjaan mereka menyediakan sesuatu yang berguna baginya" (Locke 1976 dalam Luthans 2006:243). Kepuasan kerja pada karyawan PT Kustodian Sentral Efek Indonesia diduga mengalami penurunan. Penurunan tingkat kepuasan kerja tersebut dapat dilihat pada hasil pra-research. Hasil pra-research pada Tabel 1. yang dilakukan terhadap 30 orang karyawan menunjukkan sikap karyawan yang mengindikasikan telah terjadi penurunan kepuasan kerja antara lain sikap tidak disiplin, malas bekerja, mengeluh pada pekerjaan, menghindar dari pekerjaan, stress dalam pekerjaan, dan keinginan untuk mengundurkan diri.

\begin{tabular}{|l|c|c|}
\hline \multicolumn{3}{|c|}{ TABELL 1. HASIL PRA-RESEARCHPENURUNAN KEPUASAN KERJA KARYAWAN } \\
DILLAAT DARI SIKAP KARTAWAN PT KUSTODIAN SENTRAL EFEK INDONESIA OKTOBER 2016 \\
\hline Penurunan Kepuasan Kerja Karyawan & Jumlah & Persentase \\
\hline Tidak disiplin & 8 & $27 \%$ \\
\hline Malas bekerja & 6 & $20 \%$ \\
\hline Mengeluh pada pekerjaan & 4 & $13 \%$ \\
\hline Menghindar dari pekerjaan & 3 & $10 \%$ \\
\hline Stress dalam pekerjaan & 7 & $23 \%$ \\
\hline Keinginan untuk mengundurkan diri & 2 & $7 \%$ \\
\hline Total & 30 & $100 \%$ \\
\hline \multicolumn{3}{|c|}{ Sumber: Hasil Pra-Research Oktober 2016 } \\
\hline
\end{tabular}

Berbagai macam faktor dapat mempengaruhi penurunan tingkat kepuasan kerja karyawan PT Kustodian Sentral Efek Indonesia. Faktor yang dapat mempengaruhi kepuasan kerja karyawan PT Kustodian Sentral Efek Indonesia seperti faktor kompensasi, faktor gaya kepemimpinan transaksional, faktor gaya kepemimpinan transformasional, faktor pro- 
mosi jabatan, faktor lingkungan kerja fisik, dan faktor lingkungan kerja non fisik. Hasil pra-research Tabel 2 menunjukkan bahwa penurunan tingkat kepuasan kerja karyawan PT Kustodian Sentral Efek Indonesia lebih dipengaruhi oleh faktor kepemimpinan transformasional, promosi jabatan, dan lingkungan kerja non fisik.

\begin{tabular}{|l|c|c|}
\hline \multicolumn{4}{|l|}{ TABELL2. HASIL PRA-RESEARCH VARIABEL-VARIABEL YANG MEMPENGARUHI PENURUNAN } \\
KEPUASAN KERJA KARYAWAN PT KUSTODIAN SENTRAL EFEK INDONESIA OKTOBER 2016 \\
\hline $\begin{array}{l}\text { Variabel-Variabel yang Mempengaruhi } \\
\text { Penurunan Kepuasan Kerja Karyawan }\end{array}$ & Jumlah & Persentase \\
\hline Kompensasi & 4 & $13 \%$ \\
\hline Gaya Kepemimpinan Transaksional & 3 & $10 \%$ \\
\hline Gaya Kepemimpinan Transformasional & 7 & $23 \%$ \\
\hline Promosi Jabatan & 9 & $30 \%$ \\
\hline Lingkungan Kerja Fisik & 2 & $7 \%$ \\
\hline Lingkungan Kerja Non Fisik & 5 & $17 \%$ \\
\hline Total & 30 & $100 \%$ \\
\hline \multicolumn{3}{|c|}{ Sumber : Hasil Pra-Research 0ktober 2016 } \\
\hline
\end{tabular}

Hasil wawancara yang peneliti lakukan terhadap karyawan PT Kustodian Sentral Efek Indonesia, diketahui bahwa menurut karyawan ada beberapa orang atasan di PT Kustodian Sentral Efek Indonesia yang kurang dapat mengajak dan memotivasi bawahan untuk dapat mencapai target yang ditetapkan oleh perusahaan pada umumnya serta target yang ditetapkan oleh masing-masing unit kerja pada khususnya. Sikap atasan tersebut tidak sesuai dengan pengertian kepemimpinan trans formasional, yakni seorang atasan diharapkan dapat memonitor, memotivasi, mengajak, para bawahannya serta rekan-rekan kerja lainnya untuk dapat menyatukan visi dan misi dalam mencapai suatu tujuan tertentu. "Seorang pemimpin harus dapat mengubah lingkungan kerja, motivasi kerja, pola kerja, dan nilai-nilai kerja yang dipersepsikan bawahan, sehingga mereka lebih mampu mengoptimalkan kinerja untuk mencapai tujuan perusahaan." Karyawan PT Kustodian Sentral Efek Indonesia mengharapkan sosok seorang pemimpin yang dapat melibatkan bawahan dalammengerjakan hal-hal yang lebih dari yang biasa dikerjakan bawahan, dapat mendorong bawahan untuk mencari metode baru dalam menyelesaikan pekerjaan, dapat mendengarkan masukan bawahan, serta dapat memperhatikan kebutuhan bawahan termasuk kebutuhan dalam pengembangan karir dan promosi jabatan.
Struktur organisasi yang diterapkan oleh PT Kustodian Sentral Efek Indonesia adalah struktur organisasi flat dengan dua atau tiga level manajerial. Level manajerial yang sediki dalam struktur organisasi flat otomatis membuat sedikit pula jenjang karier karyawan. Struktur organisasi flat juga akan mempersempit kesempatan karyawan untuk meraih promosi jabatan, dapat memperlambat ruang gerak ekpektasi karyawan, menurunkan motivasi karyawan, dan juga dapat mempengaruhi tendency to perform individu maupun perusahaan. Dampak negatif terparah yang kemungkinan timbul dari struktur organisasi flat ini ialah hadirnya rasa frustrasi pada diri karyawan, terutama pada karyawan yang memiliki pengaruh psikologis kuat dalam kelompok kerjanya, sehingga berujung pada timbulnya konflik akibat menurunnya tingkat kepuasan kerja yang dirasakan karyawan. PT Kustodian Sentral Efek Indonesia yang berstruktur flat, sangat disadari memiliki hambatan dalam pemenuhan kebutuhan karyawan dalam hal kenaikan jabatan. Karyawan diharuskan memenuhi standar kriteria yang telah ditetapkan oleh perusahaan dan juga kenaikan jabatan baru dapat dilaksanakan apabila posisi tujuan memang kosong, apabila masih ada pejabatnya, seorang staf dapat menduduki posisi yang sama bertahun-tahun. Jenjang karir yang sedikit menjadi salah satu ancaman dari dalam PT Kustodian Sentral Efek Indonesia. Demotivasi dan menurunnya tingkat kepuasan kerja karyawan dapat terjadi akibat dari tidak adanya kenaikan jabatan yang diharapkan karyawan.

Faktor terbesar ketiga yang mempengaruhi tingkat kepuasan kerja dari karyawan PT Kustodian Sentral Efek Indonesia berdasarkan hasil pra-research adalah lingkungan kerja non fisik. Hasil pra-research menunjukkan sebanyak $17 \%$ responden merasakan ketidakpuasan terhadap lingkungan kerja non fisik. Hasil dari wawancara juga memperlihatkan bahwa adanya gap serta hubungan yang monoton antara atasan dengan bawahan yang diakibatkan oleh selisih pendapat. Keadaan lingkungan kerja non fisik seperti ini sangat menggangu aktivitas kerja karyawan, menimbulkan rasa gelisah, serta kebosanan kerja.

Berdasarkan identifikasi masalah tersebut di atas, dirumuskan permasalahan pene- 
litian sebagai berikut: Apakah kepuasan kerja karyawan PT Kustodian Sentral Efek Indonesia dipengaruhi oleh kepemimpinan transformasional, promosi jabatan dan lingkungan kerja non fisik. Penelitian ini bertujuan untuk membuktikan dan menganalisis pengaruh kepemimpinan transformasional, promosi jabatan dan lingkungan kerja non fisik terhadap kepuasan kerja karyawan PT Kustodian Sentral Efek Indonesia.

\section{Pembatasan Masalah}

Dengan segala keterbatasan yang dimiliki oleh peneliti serta agar penelitian ini dapat lebih mudah untuk dapat dipahami dan dimengerti, maka pada penelitian ini peneliti memberikan batasan-batasan yang diteliti, yakni mengenai kepemimpinan transformasional, promosi jabatan, lingkungan kerja non fisik dan pengaruhnya terhadap kepuasan kerja karyawan di PT Kustodian Sentral Efek Indonesia, dengan cara melakukan penyebaran kuesioner kepada karyawan.

\section{KAJIAN TEORI \\ Kepuasan Kerja}

Lambrou, et. al (2010) dalam Doosti dan Afshar (2016:98), mengemukakan bahwa "kepuasan kerja adalah pernyataan positif yang dihasilkan melalui suatu pekerjaan atau pengalaman kerja." Mereka berpendapat bahwa kepuasan kerja dapat meningkatkan prestasi kerja dan organisasi sehingga harus diambil langkahlangkah untuk meningkatkan kepuasan kerja, misalnya dengan memperhatikan berbagai aspek kepentingan karyawan di masa depan. Evans (2001) dalam Indermun dan Bayat (2013:3), mendefinisikan "kepuasan kerja sebagai keadaan pikiran yang mencakup semua perasaan ditentukan oleh sejauh mana individu dapat merasakan pekerjaan terkait dirinya yang harus terpenuhi." Kepuasan kerja adalah cara untuk mengaktualisasikan diri, sehingga dapat tercapai kematangan psikologis pada diri karyawan. Karyawan kemungkinan akan merasa frustasi apabila kepuasan tidak dapat tercapai. Luthans (2006) dalam Tresna (2016:297), menunjukkan "terdapat lima dimensi yang mempengaruhi kepuasan kerja karyawan yaitu :"

1) Pekerjaan itu sendiri
2) Upah atau gaji

3) Kesempatan untuk promosi

4) Supervisi

5) Rekan kerja

\section{Kepemimpinan Transformasional}

Hughes, et. al (2012:530), menyatakan bahwa "kepemimpinan transformasional mengubah status quo dengan menggugah nilai-nilai pengikut dan pemahaman mereka kepada tujuan yang lebih tinggi." Kepemimpinan transformasional mengartikulasikan permasalahan mereka dalam sistem yang ada dan memiliki visi luar biasa mengenai bentuk masyarakat atau bentuk organisasi baru. Kepemimpinan transformasional pada akhirnya merupakan moral dalam hal meningkatkan standar perilaku manusia. Bass (1996) dalam Luthans (2014:228), menemukan bahwa "ada universalisme yang jauh lebih dalam atas kepemimpinan daripada yang telah diyakini sebelumnya". Pemimpin transformasional memperhatikan permasalahan dan kebutuhan untuk mengembangkan diri para pengikutnya. Pemimpin transformasional mampu untuk mengubah pengikutnya, serta menyadari akan adanya permasalahan dan membantu pengikutnya untuk melihat permasalahan yang lama dengan cara yang baru, serta mempunyai kemampuan membangkitkan dan mengilhami pengikutnya untuk mengeluarkan usaha ekstra agar tujuan organisasi dapat tercapai. Manajer yang paling efektif adalah pemimpin transformasional dan mereka ditandai dengan empat dimensi yakni :

1) Pengaruh Ideal (Idealized Influence). Pemimpin transformasional merupakan sumber kharisma dan menikmati kekaguman dari para pengikut mereka.

2) Motivasi Inspirasional (Inspirational Motivation). Para pemimpin ini sangat efektif dalam mengartikulasi visi, misi, dan keyakinan dengan cara yang jelas, sehingga memberikan rasa kemudahan dalam memahami tentang apa yang perlu dilakukan.

3) Stimulasi Intelektual (Intellectual Stimulation). Pemimpin transformasional bisa membuat para pengikut mereka untuk mempertanyakan paradigma lama dan menerima pandangan baru dunia tentang bagaimana hal-hal sekarang perlu di- 
lakukan.

4) Pertimbangan Individu (Individualized Consideration). Para pemimpin ini mampu mendiagnosis dan meningkatkan kebutuhan masing-masing pengikut mereka melalui pertimbangan individual, sehingga memajukan perkembangan orang-orang tersebut.

\section{Promosi Jabatan}

Dessler (2008) dalam Naveed, et. al (2011:302), menyatakan "promosi jabatan dikatakan terjadi ketika seorang karyawan dapat bergerak naik dalam hierarki jabatan dalam suatu organisasi ke tempat yang memiliki tanggung jawab yang lebih besar." Promosi dapat membuat peningkatan yang signifikan terhadap gaji, rentang kekuasaan, dan kontrol seorang karyawan. Proses promosi dapat dijadikan organisasi kompetitor sebagai sarana untuk mengidentifikasi karyawan paling produktif yang dimiliki oleh pesaingnya, pada saat yang bersamaan karyawan yang mengalami promosi jabatan tersebut semakin diakui oleh organisasi tempatnya bernaung. Promosi jabatan yang diraih oleh karyawan akan membuat karyawan tersebut merasa menjadi kontributor yang efektif dalam memenuhi target organisasi, perasaan itu kemudian akan membuat karyawan menjadi puas akan pekerjaan yang tengah mereka kerjakan. Sastrohadiwiryo (2005) dalam Ayu (2015:23), mengemukakan "dimensi dan indikator promosi jabatan yakni :"

1) Peningkatan tanggung jawab pekerjaan. Indikatornya antara lain penilaian pelaksanaan pekerjaan, pengingkatan konsistensi pekerjaan, kemungkinan pengembangan, dan keahlian yang lebih.

2) Pengembangan peningkatan tugas. Indikatornya antara lain pengalaman dan pengetahuan yang memadai, status pendidikan, dan dapat dipercaya.

\section{Lingkungan Kerja Non Fisik}

Sedarmayanti (2011:26), menyatakan bahwa "lingkungan kerja non fisik adalah semua keadaan yang terjadi yang berkaitan dengan hubungan kerja, baik hubungan dengan atasan maupun hubungan sesama rekan kerja, ataupun hubungan dengan bawahan." Wursanto (2009:269), menyebutnya "sebagai lingkungan kerja psikis yang didefinisikan sebagai sesuatu yang menyangkut segi psikis dari lingkungan kerja." Schultz dan Schultz (1994) dalam Mangkunegara (2011:105), menyatakan "lingkungan kerja non fisik adalah semua aspek fisik psikologis kerja, dan peraturan kerja yang dapat mempengaruhi kepuasan kerja dan pencapaian produktivitas." Lingkungan kerja non fisik adalah cerminan dari suasana kerja yang terjadi pada suatu organisasi. Suasana kerja yang nyaman dan kondusif akan mampu membuat seseorang lebih berkonsentrasi dalam melaksanakan tugas-tugasnya, semakin kondusif suasana kerja seseorang, makin besar pula peluangnya untuk mencari hal-hal baru yang dapat lebih meringankan. DeStefano (2006) dalam Fath (2015:22), mengemukakan "dimensi lingkungan kerja non fisik" antara lain:

1) Prosedur kerja

2) Standar kerja

3) Pertanggungjawaban supervisor

4) Kejelasan tugas

5) Sistem penghargaan

6) Hubungan antar karyawan

\section{Kerangka Pemikiran}

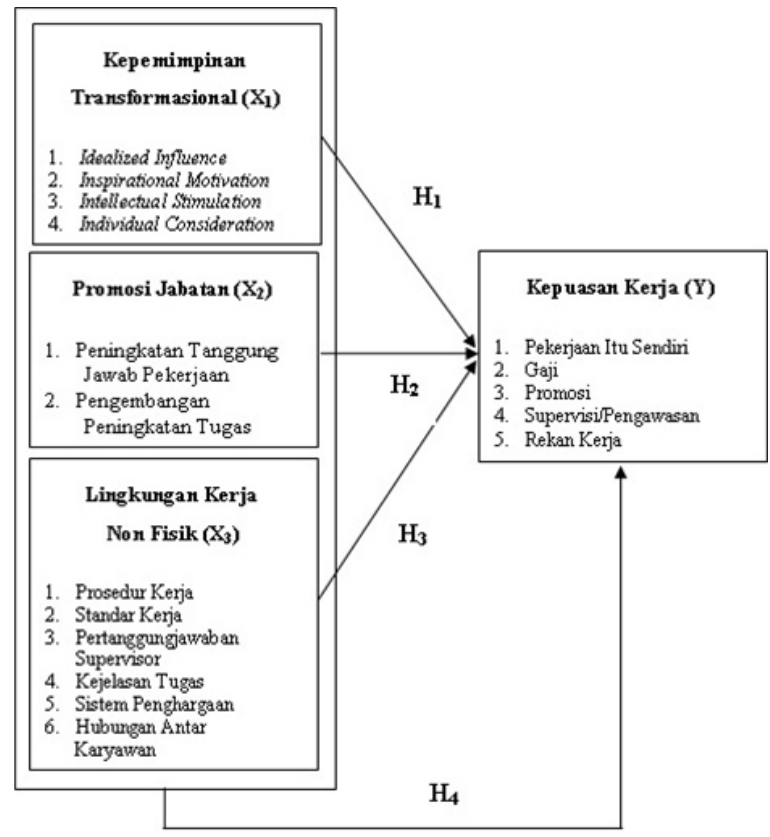

\section{GAMBAR 1. KERANGKA PEMIKIRAN HUBUNGAN DAN PENGARUH KEPEMIMPINAN TRANSFORMASIONAL, PROMOSI JABATAN, DAN LINGKUNGAN KERJA NON FISIK TERHADAP KEPUASAN KERJA KARYAWAN}

\section{Hipotesis}

Hipotesis yang dapat dibuat berdasarkan pemaparan dalam rumusan masalah dan kajian 
teori adalah sebagai berikut:

$\mathrm{H}_{1}$ : Kepemimpinan transformasional memiliki pengaruh positif terhadap kepuasan kerja karyawan.

$\mathrm{H}_{2}$ : Promosi jabatan berpengaruh positif terhadap kepuasan kerja karyawan.

$\mathrm{H}_{3}$ : Lingkungan kerja non fisik memiliki berpengaruh positif terhadap kepuasan kerja karyawan.

$\mathrm{H}_{4}$ : Kepemimpinan transformasional, promosi jabatan, dan lingkungan kerja non fisik secara bersama-sama berpengaruh positifterhadap kepuasan kerja karyawan.

\section{METODOLOGI PENELITIAN \\ Tempat dan Waktu Penelitian}

Peneliti melakukan penelitian di PT Kustodian Sentral Efek Indonesia yang beralamat di Gedung Bursa Efek Indonesia Tower 1, Lt. 5, Jl. Jend. Sudirman Kav 52-53, Jakarta 12190 pada bulan Oktober tahun 2016 hingga bulan Maret tahun 2017.

\section{Jenis Penelitian}

Dua jenis penelitian yakni penelitian deskriptif dan penelitian verifikatif digunakan dalam penelitian ini. Penelitian deskriptif aertujuan untuk memperoleh deskripsi mengenai variabel kepemimpinan transformasional, promosi jabatan, dan lingkungan kerja non fisik terhadap kepuasan kerja karyawan. Penelitian verifikatif bertujuan untuk mengetahui hubungan antar variabel melalui suatu pengujian hipotesis.

\section{Populasi dan Sampel}

Populasi pada penelitian ini berjumlah 157 orang karyawan, dan jenis pengambilan sampel yang digunakan adalah tehnik sampel jenuh yaitu jumlah keseluruhan dari populasi, maka jumlah sampel pada penelitian ini sebanyak 157 orang karyawan. Dari jumlah keseluruhan kuesioner yang disebar terdapat 18 kuesioner yang tidak kembali, maka dalam penelitian ini sampel yang digunakan menjadi 139 orang.

\section{Pengukuran}

Instrumen penelitian ini menggunakan sebuah kuesioner yang disusun dengan menggunakan skala likert jenjang lima. Sejumlah pernyataan disusun dengan jawaban responden yang berada dalam satu kontinum antara sangat setuju dan sangat tidak setuju. Kelima pilihan jawaban tersebut dibagi dalam lima kategori dengan skor yang berbeda, yaitu:

1) Sangat tidak setuju (skor 1)

2) Tidak setuju (skor 2)

3) Cukup setuju (skor 3)

4) Setuju (skor 4)

5) Sangat setuju (skor 5)

\section{Teknik Analisis}

Dalam Penelitian ini dilakukan beberapa pengujian dengan menggunakan alat statistik seperti Uji Validitas, Uji Reliabilitas, Uji F dan Uji T. Sedangkan model analisis yang menggunakan regresi berganda, dengan formulasi sebagai berikut:

$$
\mathrm{Y}=\boldsymbol{\alpha}+\boldsymbol{\beta}_{1} \mathrm{X}_{1}+\beta_{2} \mathrm{X}_{2}+\beta_{3} \mathrm{X}_{3}+€
$$

Keterangan :

$\mathrm{Y}=$ Variabel Kepuasan Kerja

$\alpha=$ Parameter Konstanta

$\beta=$ Nilai Koefisiensi Regresi

$\mathrm{X}_{1}=$ Variabel Kepemimpinan Transformasional

$\mathrm{X}_{2}=$ Variabel Promosi Jabatan

$\mathrm{X}_{3}=$ Variabel Lingkungan Kerja Non Fisik

$€ \quad=$ Standar Error

\section{HASIL PENELITIAN DAN PEMBAHASAN Hasil Penelitian \\ Karakteristik Responden}

Data hasil pengukuran melalui kuisioner terhadap 100 orang responden adalah sebagai berikut: diketahui bahwa responden laki-laki lebih banyak daripada responden perempuan, dengan persentase $58,27 \%$ berbanding $41,73 \%$ responden perempuan. Responden dengan karakteristik usia didominasi oleh responden berusia 23-32 dengan persentase $49,64 \%$. Responden berusia 33-42 tahun memiliki persentase $23,74 \%$ dan responden berusia 43 52 memiliki persentase 26,62\%. Responden dengan karakteristik tingkat pendidikan didominasi oleh responden dengan tingkat pendidikan Sarjana (S1) dengan persentase 65,47\%. Responden yang memiliki tingkat pendidikan Pasca Sarjana (S2) memiliki persentase 16,55\%. Responden yang memiliki tingkat pendidikan SLTA/Sederajat memiliki persentase 9,35\%. Responden yang memiliki tingkat pendidikan 
Diploma (D3) memiliki persentase 5,76\%. Responden yang memiliki tingkat pendidikan SLTP/Sederajat memiliki persentase 2,88\%. Responden dengan tingkat jabatan clerk (office boy dan driver) memiliki persentase 10,07\%. Responden dengan tingkat jabatan staf memiliki persentase $69,06 \%$. Responden dengan tingkat jabatan kepala unit memiliki persentase $15,11 \%$. Responden dengan tingkat jabatan kepala divisi memiliki persentase $6,76 \%$.

\section{Hasil Uji Validitas dan Reliabilitas Instrumen Penelitian}

"Validitas menunjukkan sejauh mana suatu alat ukur itu mengukur apa yang ingin diukur." Metode pendekatan korelasi product moment digunakan dalam pengujian validitas instrumen dengan ketentuan suatu instrument dapat dinyatakan valid apabila nilai $\mathrm{r}_{\text {hitung }}>$ nilai $\mathrm{r}_{\text {tabel }}$ pada $\mathrm{N}=139$. Hasil penghitungan terlihat semua item pernyataan dalam kuesioner sudah memenuhi syarat valid, yaitu nilai $\mathrm{r}_{\text {hitung }}>\mathrm{r}_{\text {tabel }}$ dan Sig. $<0,05$, sehingga dapat disimpulkan bahwa instrumen yang digunakan dapat dilanjutkan untuk membahas permasalahan dalam penelitian ini.

\begin{tabular}{|c|c|c|c|c|}
\hline \multicolumn{5}{|c|}{ TABEL 3. HASIL UJI VALLDITAS VARIABEL KEPEMIMPINAN TRANSFORMASIONAL } \\
\hline No & Item Pernyataan & $\mathbf{r}_{\text {hitung }}$ & $r_{\text {tabel }}$ & Kriteria \\
\hline 1 & $x_{1} 1$ & 0,750 & 0,167 & Valid \\
\hline 2 & $x_{r}{ }^{2}$ & 0,713 & 0,167 & Valid \\
\hline 3 & $x_{1} 3$ & 0,680 & 0,167 & Valid \\
\hline 4 & $\mathrm{X}_{\mathrm{r}} 4$ & 0,692 & 0,167 & Valid \\
\hline 5 & $X_{1} .5$ & 0,615 & 0,167 & Valid \\
\hline 6 & $x_{1} 6$ & 0,700 & 0,167 & Valid \\
\hline 7 & $\mathrm{X}_{\mathrm{r}} 7$ & 0,582 & 0,167 & Valid \\
\hline 8 & $x_{1} 8$ & 0,619 & 0,167 & Valid \\
\hline 9 & $x_{1} 9$ & 0,813 & 0,167 & Valid \\
\hline 10 & $x_{1} 10$ & 0,647 & 0,167 & Valid \\
\hline 11 & $X_{1} .11$ & 0,600 & 0,167 & Valid \\
\hline 12 & $x_{1} 12$ & 0,705 & 0,167 & Valid \\
\hline 13 & $x_{1} 13$ & 0,647 & 0,167 & Valid \\
\hline 14 & $X_{\mathrm{r}} 14$ & 0,763 & 0,167 & Valid \\
\hline 15 & $X_{1}, 15$ & 0,658 & 0,167 & Valid \\
\hline 16 & $\mathrm{X} 1.16$ & 0,709 & 0,167 & Valid \\
\hline \multicolumn{5}{|c|}{ Sumber : Data Primer Diolah SPSS Versi 20, Maret 2017} \\
\hline
\end{tabular}

TABELL 4. HASIL UJ VALLDITAS VARIABELL PROMOSI JABATAN

\begin{tabular}{|c|c|c|c|c|}
\hline No & Item Pernyataan & $\mathbf{r}_{\text {htung }}$ & $\mathbf{r}_{\text {tabel }}$ & Kriteria \\
\hline 1 & $\mathrm{X}_{2} \cdot 1$ & 0,684 & 0,167 & Valid \\
\hline 2 & $X_{2} \cdot 2$ & 0,750 & 0,167 & Valid \\
\hline
\end{tabular}

\begin{tabular}{|c|c|c|c|c|}
\hline 3 & $\mathrm{X}_{2} \cdot 3$ & 0,746 & 0,167 & Valid \\
\hline 4 & $\mathrm{X}_{2} \cdot 4$ & 0,701 & 0,167 & Valid \\
\hline 5 & $\mathrm{X}_{2} \cdot 5$ & 0,757 & 0,167 & Valid \\
\hline 6 & $\mathrm{X}_{2} \cdot 6$ & 0,612 & 0,167 & Valid \\
\hline 7 & $\mathrm{X}_{2} \cdot 7$ & 0,587 & 0,167 & Valid \\
\hline \multicolumn{5}{|c|}{ Sumber : Data Primer Diolah SPSS Versi 20, Maret 2017 } \\
\hline
\end{tabular}

\begin{tabular}{|c|c|c|c|c|}
\hline No & Item Pernyataan & $\mathbf{r}_{\text {hitung }}$ & $r_{\text {tabel }}$ & Kriteria \\
\hline 1 & $X_{3} 1$ & 0,647 & 0,167 & Valid \\
\hline 2 & $x_{3} \cdot 2$ & 0,659 & 0,167 & Valid \\
\hline 3 & $x_{3} \cdot 3$ & 0,736 & 0,167 & Valid \\
\hline 4 & $x_{3} \cdot 4$ & 0,650 & 0,167 & Valid \\
\hline 5 & $x_{3} \cdot 5$ & 0,627 & 0,167 & Valid \\
\hline 6 & $x_{3} \cdot 6$ & 0,621 & 0,167 & Valid \\
\hline 7 & $X_{3} .7$ & 0,656 & 0,167 & Valid \\
\hline 8 & $X_{3} .8$ & 0,680 & 0,167 & Valid \\
\hline 9 & $X_{3} \cdot 9$ & 0,566 & 0,167 & Valid \\
\hline 10 & $X_{3} \cdot 10$ & 0,441 & 0,167 & Valid \\
\hline 11 & $X_{3} .11$ & 0,396 & 0,167 & Valid \\
\hline 12 & $X_{3} \cdot 12$ & 0,586 & 0,167 & Valid \\
\hline 13 & $X_{3} 13$ & 0,629 & 0,167 & Valid \\
\hline 14 & $X_{3} 14$ & 0,633 & 0,167 & Valid \\
\hline 15 & $X_{3} 15$ & 0,573 & 0,167 & Valid \\
\hline 16 & $X_{3} 16$ & 0,719 & 0,167 & Valid \\
\hline 17 & $X_{3} 17$ & 0,599 & 0,167 & Valid \\
\hline 18 & $X_{3} 18$ & 0,456 & 0,167 & Valid \\
\hline \multicolumn{5}{|c|}{ Sumber : Data Primer Diolah SPSS Versi 20, Maret 2017} \\
\hline
\end{tabular}

TABEL 6. HASIL UJ VALLDITAS VARIABEL KEPUASAN KERJA

\begin{tabular}{|c|c|c|c|c|}
\hline No & Item Pernyataan & $\mathbf{r}_{\text {hitung }}$ & $\mathbf{r}_{\text {tabel }}$ & Kriteria \\
\hline 1 & $Y .1$ & 0,601 & 0,167 & Valid \\
\hline 2 & $Y .2$ & 0,515 & 0,167 & Valid \\
\hline 3 & $Y .3$ & 0,615 & 0,167 & Valid \\
\hline 4 & $Y .4$ & 0,683 & 0,167 & Valid \\
\hline 5 & $Y .5$ & 0,691 & 0,167 & Valid \\
\hline 6 & $Y .6$ & 0,706 & 0,167 & Valid \\
\hline 7 & $Y .7$ & 0,739 & 0,167 & Valid \\
\hline 8 & $Y .8$ & 0,757 & 0,167 & Valid \\
\hline 9 & $Y .9$ & 0,759 & 0,167 & Valid \\
\hline 10 & $Y .10$ & 0,655 & 0,167 & Valid \\
\hline 11 & $Y .11$ & 0,689 & 0,167 & Valid \\
\hline 12 & $Y .12$ & 0,466 & 0,167 & Valid \\
\hline 13 & $Y .13$ & 0,416 & 0,167 & Valid \\
\hline 14 & $Y .14$ & 0,374 & 0,167 & Valid \\
\hline 15 & $Y .15$ & 0,260 & 0,167 & Valid \\
\hline & \multicolumn{5}{|c|}{ Sumber : Data Primer Diolah SPsS Versi 20, Maret 2017 } \\
\hline
\end{tabular}


"Uji reliabilitas digunakan untuk mengukur ketepatan suatu instrumen, suatu instrumen pengukuran dikatakan reliabel bila memberikan hasil score yang konsisten pada setiap pengukuran." Metode rumus korelasi Alpha Cronbach digunakan dalam pengujian reliabilitas instrumen dengan ketentuan nilai Alpha Cronbach > 0,6. Hasil penghitungan terlihat bahwa semua variabel penelitian ini dinyatakan reliabel. Dengan demikian, data yang dipergunakan telah layak digunakan pada analisis berikutnya.

TABEL 7. HASIL UJI RELIABILITAS VARIABEL PENELITIAN

\begin{tabular}{|c|c|c|}
\hline Variabel & $\begin{array}{c}\text { Alpha Cronbach- } \\
\text { hitung }\end{array}$ & Keputusan \\
\hline Kepemimpinan Transformasional & 0,923 & \multirow{4}{*}{$\begin{array}{c}\text { Reliabel } \\
\text { Alpha } \\
\text { Cronbach } \\
\text { pada masing- } \\
\text { masing } \\
\text { variabel }>0,6\end{array}$} \\
\hline Promosi Jabatan & 0,818 & \\
\hline Lingkungan Kerja Non Fisik & 0,900 & \\
\hline Kepuasan Kerja & 0,864 & \\
\hline
\end{tabular}

\section{Hasil Uji Asumsi Klasik}

\section{1) Uji Normalitas}

"Uji normalitas digunakan untuk menguji apakah suatu model regresi, residual terdistribusi secara normal. Kriteria normalitas dapat diketahui dengan melihat probability plot yang membandingkan distribusi kumulatif dari distribusi normal. Distribusi normal akan membentuk satu garis lurus diagonal, dan plotting data residual akan dibandingkan dengan residualnya. Distribusi data residual dapat dikatakan terdistribusi normal maka garis yang menggambarkan data sesungguhnya akan mengikuti garis diagonalnya."

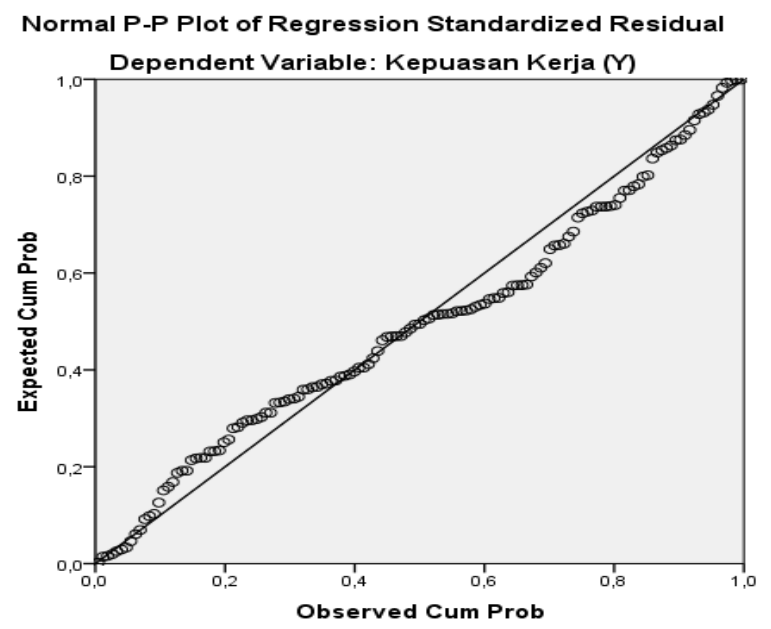

GAMBAR 2. GRAFIK P-PLOT NORMALITAS
Gambar 2. menggambarkan bahwa data penelitian dalam model regresi terdistribusi secara normal. Distribusi normal ini dapat dilihat melalui garis yang menggambarkan data sesungguhnya mengikuti garis diagonal. Gambar tersebut mengartikan bahwa sebaran data dikatakan tersebar disekeliling garis lurus (tidak terpencar jauh dari garis lurus), sehingga normalitas terpenuhi. Model regresi berdasarkan pengujian ini dapat dikatakan terdistribusi normal dan bisa dilanjutkan ke pengujian selanjutnya.

\section{2) Uji Multikolinearitas}

"Uji multikolinearitas digunakan untuk melihat hubungan korelasi antar variabel bebas, model regresi yang baik seharusnya tidak terjadi korelasi di antara variabel independen, jika variabel independen saling berkorelasi maka variabel-variabel ini tidak ortogonan." Variabel ortogonan adalah variabel independen yang nilai korelasi antar sesama variabel independen sama dengan nol. Uji multikolinearitas dapat diketahui dari tabel coefficients hasil regresi atas variabel kepemimpinan transformasional $\left(\mathrm{X}_{1}\right)$, promosi jabatan $\left(\mathrm{X}_{2}\right)$, dan lingkungan kerja non fisik $\left(\mathrm{X}_{3}\right)$ terhadap variabel kepuasan kerja $(\mathrm{Y})$, seperti tertera di tabel berikut :

\begin{tabular}{|l|c|c|}
\hline \multicolumn{3}{|c|}{ TABEL 8. HASIL UJ MULTIKOLINEARITAS } \\
\hline Variabel & Tolerance & VIF \\
\hline Kepemimpinan Transformasional $\left(X_{1}\right)$ & 0,675 & 1,481 \\
\hline Promosi Jabatan $\left(X_{2}\right)$ & 0,789 & 1,268 \\
\hline Lingkungan Kerja Non Fisik $\left(X_{3}\right)$ & 0,642 & 1,557 \\
\hline \multicolumn{3}{|c|}{ sumber : Data Primer Diolah SPSS Versi 20, Maret 2017 } \\
\hline
\end{tabular}

Data penelitian pada Tabel 3. dapat dikatakan tidak menunjukkan suatu gejala multikolinearitas apabila nilai VIF $<10,00$ dan memiliki nilai tolerance $>0,10$. Tabel 5.12. menunjukkan variabel kepemimpinan transformasional $\left(\mathrm{X}_{1}\right)$ memiliki besaran nilai VIF $1,481<10,00$ dan nilai tolerance $0,675>0,10$ terhadap variabel kepuasan kerja (Y), maka dapat dikatakan variabel kepemimpinan transformasional tidak terjadi gejala multikolinearitas. Variabel promosi jabatan $(\mathrm{XZ})$ memiliki besaran nilai VIF 1,268 $<10,00$ dan nilai tolerance $0,789>0,10$ terhadap variabel kepuasan kerja (Y), maka dapat dikatakan variabel promosi jabatan tidak terjadi gejala multikolinearitas. Variabel lingkungan kerja non 
fisik $\left(\mathrm{X}_{3}\right)$ mempunyai besaran nilai VIF $1,557<$ 10,00 dan nilai tolerance $0,642>0,10$ terhadap variabel kepuasan kerja (Y), maka dapat dikatakan variabel lingkungan kerja non fisik tidak terjadi gejala multikolinearitas.

\section{3) Uji Heterokedastisitas}

Uji heterokedastisitas digunakan untuk dapat mengetahui ada atau tidaknya heterokedastisitas, salah satunya dengan menggunakan grafik plot antara nilai terikat dengan residualnya. Uji heterokedastisitas untuk menunjukkan nilai varians (Y-Y) antar nilai Y tidak konstant atau sama dari satu pengamatan ke pengamatan lain. Gejala heterokedastisitas dapat diketahui dengan melihat diagram pancar, apabila diagram pancar yang ada membentuk suatu pola tertentu yang teratur maka regresi memiliki gangguan heterokedastisitas. Model regresi dapat dikatakan tidak mengalami gangguan heterokedastisitas jika diagram pancar membentuk pola acak.

Gambar 3. dibawah ini menunjukkan diagram pancar tidak membentuk pola tertentu atau acak menyebar diatas dan dibawah angka 0 pada sumbu $\mathrm{Y}$, sehingga bisa dinyatakan bahwa regresi tidak terjadi gangguan heterokedastisitas.

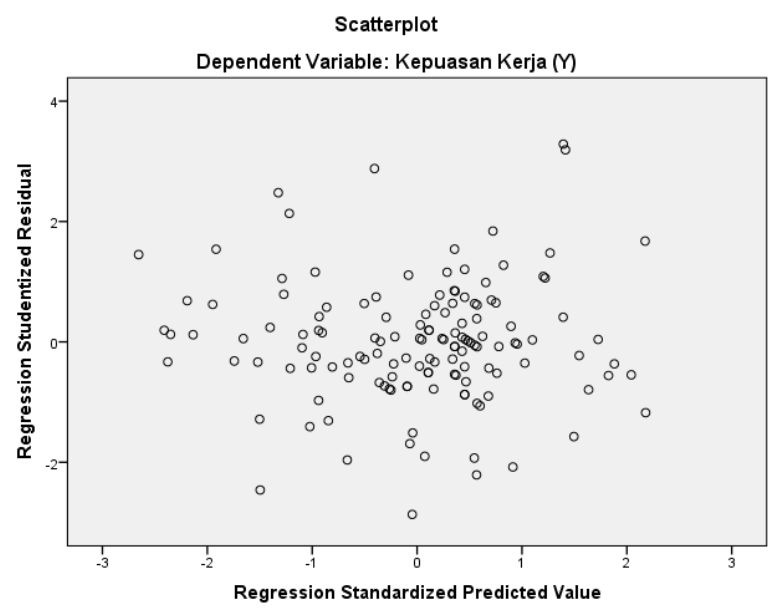

GAMBAR 3. GRAFIK PLOT HETEROKEDASTISITAS

Sumber : Data Primer Diolah SPSS Versi 20, Maret 2017

\section{Analisis Regresi Berganda}

Penggunaan analisis regresi linier berganda dalam penelitian ini akan memperlihatkan apakah kepemimpinan transformasional, promosi jabatan, dan lingkungan kerja non fisik berpengaruh terhadap kepuasan kerja karyawan. Hasil pengujian regresi linier berganda terangkum dalam Tabel 4.

\begin{tabular}{|l|c|c|c|c|}
\hline \multicolumn{5}{|c|}{ TABEL 9. HASIL ANALISIS REGRESI LINEAR } \\
\hline \multicolumn{1}{|c|}{ Variabel } & $\begin{array}{c}\text { Koefisien } \\
\text { Regresi }\end{array}$ & Beta & $\mathbf{t}$ & Sig \\
\hline Konstanta & 4,312 & & & \\
\hline $\begin{array}{l}\text { Kepemimpinan } \\
\text { Transformasional }\left(X_{1}\right)\end{array}$ & 0,118 & 0,146 & 2,079 & 0,040 \\
\hline Promosi Jabatan $\left(X_{2}\right)$ & 0,429 & 0,210 & 3,224 & 0,002 \\
\hline $\begin{array}{l}\text { Lingkungan Kerja } \\
\text { Non Fisik }\left(X_{3}\right)\end{array}$ & 0,457 & 0,530 & 7,355 & 0,000 \\
\hline$F_{\text {hitung }}=54,897$ & & \\
\hline$R^{2}=0,540$ & Sumber : Data Primer Diolah SPSS Versi 20, Maret 2017 \\
\hline \multicolumn{5}{|c|}{} \\
\hline
\end{tabular}

Merujuk pada Tabel 4. didapat model persamaan regresi sebagai berikut:

$$
Y=4,312+0,118 X_{1}+0,429 X_{2}+0,457 X_{3}
$$

\section{Analisis Koefisien Determinasi (R-Square)}

Tabel 5.14. menunjukkan hasil analisis data dengan menggunakan alat bantu SPSS versi 20 diperoleh nilai koefisien determinasi $\left(\mathrm{R}^{2}\right)$ sebesar 0,540. Koefisien tersebut mendefinisikan bahwa sumbangan relatif yang diberikan oleh kombinasi variabel kepemimpinan transformasional $\left(\mathrm{X}_{1}\right)$, variabel promosi jabatan $\left(\mathrm{X}_{3}\right)$, variabel lingkungan kerja non fisik $\left(\mathrm{X}_{3}\right)$ terhadap variabel kepuasan kerja $(\mathrm{Y})$ sebesar $54 \%$ sedangkan variabel lain yang tidak diteliti mempengaruhi sisanya.

\section{Pembahasan \\ Hipotesis 1}

Variabel kepemimpinan transformasional berpengaruh positif dan signifikan terhadap kepuasan kerja karyawan dengan nilai thitung $2,079>\mathrm{t}_{\text {tabel }} 1,978$ dan nilai signifikansi 0,040 $<0,05$. Hal tersebut menunjukkan bahwa variabel kepemimpinan transformasional telah teruji dan pernyataan hipotesis 1 dapat diterima. Penelitian yang telah dilakukan memberikan pembuktian secara empiris bahwa kepemimpinan transformasional memberikan pengaruh signifikan terhadap kepuasan kerja karyawan PT Kustodian Sentral Efek Indonesia. Kepemimpinan transformasional diharapkan mampu memberikan dampak positif terhadap peningkatan kepuasan kerja karyawan PT Kustodian Sentral Efek Indonesia.

Hasil temuan sejalan dengan penelitian Long, et. al (2014), yang menyatakan "kepemimpinan transfomasional berhubungan posi- 
tif dengan kepuasan kerja, artinya jika kepemimpinan transformasional menurun maka kepuasan kerja juga akan menurun." Hasil penelitian terdahulu yang dilakukan Emmanuel dan Hasan (2015), menyatakan "kepemimpinan transformasional memiliki pengaruh yang positif terhadap kepuasan kerja, hal ini menunjukkan jika para pemimpin lebih sering terlibat dalam mengajak dan mengikutsertakan karyawan dalam suatu pekerjaan, secara langsung akan meningkatkan kepuasan kerja karyawan."

Jung dan Sosik dalam Ponpearchan (2016:55), menyatakan bahwa "pemimpin transformasional memperhatikan hal-hal kebutuhan pengembangan dari masing-masing para pengikut dan persoalan-persoalan dengan membantu mereka memandang masalah lama dengan cara-cara baru, dan mereka mampu menggairahkan, membangkitkan, dan mengilhami pengikut untuk mengeluarkan upaya ekstra demi mencapai saran kelompok." Kepemimpinan transformasional merupakan seorang yang memiliki visi sebagai agen perubahan pada sebuah organisasi dan bawahannya dalam mengubah lingkungan kerja dengan meningkatkan moralitas dan motivasi yang tinggi pada bawahan dan juga menghargai serta memperhatikan kebutuhan-kebutuhan bawahannya sehingga bawahan dapat mengoptimalkan kinerjanya untuk mencapai tujuan organisasi.

\section{Hipotesis 2}

Variabel promosi jabatan berpengaruh positif dan signifikan terhadap kepuasan kerja karyawan dengan nilai $\mathrm{t}_{\text {hitung }} 3,224>\mathrm{t}_{\text {tabel }}$ 1,978 dan nilai signifikansi $0,002<0,05$. Hal tersebut menunjukkan bahwa variabel promosi jabatan telah teruji dan pernyataan hipotesis 2 dapat diterima. Penelitian yang telah dilakukan memberikan pembuktian secara empiris bahwa promosi jabatan berpengaruh signifikan terhadap kepuasan kerja karyawan PT Kustodian Sentral Efek Indonesia. Promosi jabatan diharapkan mampu memberikan dampak positif terhadap peningkatan kepuasan kerja karyawan PT Kustodian Sentral Efek Indonesia.

Hasil temuan ini sejalan dengan penelitian Muhammad dan Akhter (2010), yang menyatakan bahwa "promosi jabatan memiliki pengaruh positif atas kepuasan kerja karyawan, setelah menerima promosi jabatan para karyawan akan merasa senang dan merasa mampu untuk dapat memenuhi segala tuntutan hidup mereka." Hasil temuan penelitian terdahulu yang dilakukan oleh Mustapha dan Zakaria (2013), menyatakan "promosi jabatan memiliki korelasi positif terhadap kepuasan kerja”. Setiap perusahaan atau instansi harus mempertimbangkan peluang promosi bagi karyawan yang telah memenuhi kriteria dan syarat untuk dipromosikan ke posisi yang lebih tinggi agar mereka merasakan kepuasan dalam bekerja. Hasil temuan penelitian Noor, et al (2015), menyatakan "promosi jabatan memiliki pengaruh positif dan signifikan atas kepuasan kerja, artinya kepuasan kerja karyawan dapat ditingkatkan dengan cara membuat kebijakan promosi kerja yang baik serta memberikan peluang secara adil."

Siagian (2009:169), menyatakan "promosi jabatan adalah pemindahan pegawai atau karyawan, dari satu jabatan atau tempat kepada jabatan atau tempat yang lebih tinggi serta diikuti oleh tugas, tanggung jawab, dan wewenang yang lebih tinggi dari jabatan yang diduduki sebelumnya." Pengaruh promosi jabatan terhadap kepuasan kerja dapat dilihat dari ketika setiap karyawan mendapatkan kesempatan untuk dipromosikan berdasarkan asas keadlilan dan objektivitas maka karyawan akan terdorong untuk bekerja dengan giat, bersemangat, berdisiplin, serta berprestasi dalam pekerjaan sehingga target yang ingin diraih oleh perusahaan dapat tercapai maksimal. Kepuasan kerja, gairah kerja dan disiplin akan menurun apabila kesempatan karyawan untuk dipromosikan kecil atau bahkan tidak ada. Promosi jabatan yang diraih oleh karyawan akan membuat karyawan tersebut merasa menjadi kontributor yang efektif dalam memenuhi target organisasi, perasaan itu kemudian akan membuat karyawan menjadi puas akan pekerjaan yang tengah mereka kerjakan.

\section{Hipotesis 3}

Variabel lingkungan kerja non fisik berpengaruh positif dan signifikan terhadap kepuasan kerja karyawan dengan nilai nilai $\mathrm{t}_{\text {hitung }}$ $7,355>\mathrm{t}_{\text {tabel }}$ 1,978 dan nilai signifikansi 0,000 $<0,05$. Hal tersebut memperlihatkan variabel lingkungan kerja non fisik telah teruji dan 
pernyataan hipotesis 3 dapat diterima. Penelitian yang telah dilakukan memberikan pembuktian secara empiris bahwa lingkungan kerja non fisik berpengaruh signifikan terhadap kepuasan kerja karyawan PT Kustodian Sentral Efek Indonesia. lingkungan kerja non fisik diharapkan mampu memberikan dampak positif terhadap peningkatan kepuasan kerja karyawan PT Kustodian Sentral Efek Indonesia.

Temuan ini sejalan dengan penelitian Tio (2014), yang menyatakan bahwa "lingkungan kerja non fisik berpengaruh signifikan terhadap kepuasan kerja karyawan, artinya setiap perusahaan atau instansi harus memperhatikan lingkungan kerja non fisik seperti sikap saling mendukung dan toleransi sesama karyawan." Hasil temuan penelitian Jain dan Kaur (2014), menyebutkan "lingkungan kerja non fisik memiliki pengaruh positif terhadap kepuasan kerja. Faktor tugas dan tanggung jawab, fasilitas penyegaran dan rekreasi, prosedur kerja, suasana tempat kerja serta fasilitas kesehatan dan keselamatan dapat membuat karyawan merasakan kepuasan kerja sehingga mereka akan bertahan bekerja di tempat tersebut." Hasil temuan penelitian Muhammad, et all (2015), mengemukakan bahwa "lingkungan kerja non fisik berpengaruh positif dan signifikan terhadap kepuasan kerja." Faktor-faktor lingkungan kerja non fisik seperti kebijakan manajemen, hubungan sesama karyawan, hubungan antara bawahan dengan pimpinan harus diperhatikan oleh manajemen demi menciptakan rasa kepuasan dalam bekerja dalam diri karyawan.

Schultz dan Schultz (1994) dalam Mangkunegara (2011:105), menyatakan "lingkungan kerja non fisik adalah semua aspek fisik psikologis kerja, dan peraturan kerja yang dapat mempengaruhi kepuasan kerja dan pencapaian produktivitas." Lingkungan kerja non fisik bertujuan untuk membentuk sikap para karyawan yang bekerja di perusahaan. Sikap yang diharapkan adalah sikap yang positif dimana sikap tersebut dapat mendukung pelaksanaan kerja para karyawan yang dapat menjamin pencapaian tujuan dalam organisasi. "Lingkungan kerja non fisik merupakan cermin dari suasana kerja yang terjadi dalam suatu organisasi." Suasana kerja yang nyaman dan kondusif akan mampu membuat seseorang lebih berkonsentrasi dalam melaksanakan tugas-tugasnya, semakin kondusif suasana kerja seseorang, makin besar pula peluangnya untuk mencari hal-hal baru yang dapat lebih meringankan beban pekerjaan.

\section{Hipotesis 4}

Pernyataan hipotesis 4 dapat diterima karena nilai nilai $\mathrm{F}_{\text {hitung }} 54,897>\mathrm{t}_{\text {tabel }} 2,67$ dan nilai signifikansi $0,000<0,05$. Data statistik berarti $\mathrm{H}_{0}$ ditolak dan $\mathrm{H}_{\mathrm{a}}$ diterima, yang artinya variabel kepemimpinan transformasional, promosi jabatan, dan lingkungan kerja non fisik berpengaruh secara bersama-sama dan signifikan terhadap kepuasan kerja karyawan PT Kustodian Sentral Efek Indonesia.

\section{KESIMPULAN dan SARAN Kesimpulan}

Penelitian yang sudah dilakukan menunjukkan hasil yang signifikan dari ketiga variabel independen yaitu: kepemimpinan transformasional, promosi jabatan, dan lingkungan kerja non fisik terhadap variabel dependen yaitu kepuasan kerja karyawan. Hal tersebut mengindikasikan faktor kepemimpinan transformasional, promosi jabatan, dan lingkungan kerja non fisik merupakan faktor penting yang dapat mempengaruhi kepuasan kerja karyawan.

1) Hasil penelitian menunjukkan bahwa variabel lingkungan kerja non fisik merupakan variabel yang paling signifikan mempengaruhi kepuasan kerja karyawan PT Kustodian Sentral Efek Indonesia. Hasil penelitian tersebut berbeda dengan hasil pra research yang menunjukkan bahwa variabel promosi jabatan sebagai variabel yang paling mempengaruhi kepuasan kerja karyawan PT Kustodian Sentral Efek Indonesia. Perbedaan hasil tersebut terjadi karena kuesioner pra research lebih banyak diberikan kepada karyawankaryawan muda dengan kisaran umur 2332 Karyawan muda tersebut beranggapan bahwa mendapatkan sebuah promosi jabatan merupakan sesuatu yang paling diharapkan dalam perjalanan karir mereka selama bekerja di PT Kustodian Sentral Efek Indonesia.

2) Tingginya tingkat signifikansi yang diperoleh variabel lingkungan kerja non fisik dibandingkan dengan variabel kepe- 
mimpinan transformasional dan variabel promosi jabatan pada hasil penelitian tidak terlepas dari minimnya pemimpin yang inspiratif bagi karyawan serta struktur organisasi flat structure organization yang dianut oleh perusahaan mempersempit kesempatan karyawan meraih promosi jabatan menjadi salah satu kekurangan yang dimiliki PT Kustodian Sentral Efek Indonesia. Karyawan beranggapan lingkungan kerja non fisik seperti prosedur kerja, standar kerja pertanggungjawaban supervisor, kejelasan tugas, sistem penghargaan, dan hubungan antar karyawan menjadi solusi untuk dapat meminimalisir dampak yang dihasilkan dari kekurangan dalam hal kepemimpinan dan promosi jabatan tersebut.

3) Variabel kepemimpinan transformasional berpengaruh positif dan signifikan terhadap kepuasan kerja karyawan PT Kustodian Sentral Efek Indonesia. Dimensi kepemimpinan transformasional yang memiliki korelasi tertinggi dengan dimensi kepuasan kerja yakni dimensi Inspirational Motivation terhadap dimensi pengawasan atau supervisi. Hal tersebut menunjukkan bahwa karyawan mengharapkan sosok seorang pemimpin yang dapat menginspirasi karyawan serta optimal dalam melakukan pengawasan atau supervisi, diantaranya dengan menentukan standar tinggi, memberikan keyakinan kalau suatu tujuan dapat diraih, efektif dalam mengartikulasi visi, misi, dan keyakinan dengan cara yang jelas sehingga memberikan rasa kemudahan pada diri karyawan dalam memahami tentang hal yang perlu dilakukan serta berperan aktif mengawasi apa yang sedang dikerjakan dan apa yang tengah dirasakan karyawannya. Sikap karyawan tidak disiplin dan malas bekerja yang muncul pada saat pra research dilakukan, diakibatkan kurangnya tindakan pengawasan atau supervisi yang dilakukan oleh atasan serta kurangnya atasan dalam hal menginspirasi bawahan saat melakukan rutinitas pekerjaannya.

4) Variabel promosi jabatan berpengaruh positif dan signifikan terhadap kepuasan kerja karyawan PT Kustodian Sentral Efek Indonesia. Dimensi promosi ja- batan yang memiliki korelasi tertinggi dengan dimensi kepuasan kerja yakni dimensi pengembangan peningkatan tugas terhadap dimensi pekerjaan itu sendiri. Hal tersebut menunjukkan bahwa pekerjaan atau jobdesc karyawan perlu dikembangkan dan ditingkatan demi mengukur dan mengeluarkan kemampuan maksimal karyawan dalam melakukan pekerjaan tersebut serta demi melihat apakah mereka memang pantas untuk meraih promosi dan bertanggung jawab atas pekerjaan yang lebih kompleks. Pengembangan peningkatan tugas seorang karyawan dapat dilakukan dengan melihat pengalaman, pengetahuan yang memadai, status pendidikan, serta kepercayaan seorang pemimpin terhadap karyawan tersebut. Sikap karyawan mengeluh pada pekerjaan, menghindar dari pekerjaan dan stress dalam pekerjaan yang muncul pada saat pra research dilakukan, diakibatkan dari minimnya kesempatan karyawan mendapatkan pengembangan dan peningkatan tugas sehingga timbul kejenuhan dalam diri karyawan karena harus melakukan pekerjaan dan rutinitas yang sama secara terus menerus dalam jangka waktu lama.

5) Variabel lingkungan kerja non fisik berpengaruh positif dan signifikan terhadap kepuasan kerja karyawan PT Kustodian Sentral Efek Indonesia. Dimensi lingkungan kerja non fisik yang memiliki korelasi tertinggi dengan dimensi kepuasan kerja yakni dimensi sistem penghargaan terhadap dimensi kesempatan promosi. Hal tersebut menunjukkan bahwa kesempatan promosi merupakan suatu bentuk penghargaan yang paling didambakan oleh karyawan karena apabila seorang karyawan memiliki kesempatan mendapatkan promosi maka karyawan tersebut merasa dihargai kinerjanya serta dianggap dapat diandalkan oleh perusahaan. Sikap karyawan ingin mengundurkan diri yang muncul pada saat pra research dilakukan, diakibatkan dari minimnya kesempatan promosi yang diberikan oleh perusahaan kepada karyawan menimbulkan kesan kurang dihargainya karyawan yang telah memberikan kontribusi maksimal bagi 
kemajuan PT Kustodian Sentral Efek Indonesia.

\section{Saran}

Hal-hal yang disarankan perlu diperhatikan agar kepuasan kerja karyawan PT Kustodian Sentral Efek Indonesia dapat ditingkatkan berdasarkan dari hasil penelitian dan kesimpulan yakni:

1) Dimensi variabel kepemimpinan transformasional yang memiliki nilai korelasi tertinggi adalah dimensi Inspirational $\mathrm{Mo}$ tivation. Hal tersebut menunjukkan bahwa karyawan PT Kustodian Sentral Efek Indonesia membutuhkan pemimpin yang dapat memberikan inspirasi dengan sering memberikan saran kepada para karyawan ketika karyawan menemukan kesulitan serta dapat memutar sudut pandang karyawan untuk dapat melihat dengan sudut pandang baru yang jauh lebih baik dari sebelumnya.

2) Dimensi variabel promosi jabatan yang memiliki nilai korelasi tertinggi adalah dimensi pengembangan peningkatan tugas. Hal tersebut menunjukkan bahwa pengembangan peningkatan tugas sebaiknya menjadi prioritas utama yang harus diperhatikan oleh perusahaan dalam rangka meningkatkan kepuasan kerja karyawan dalam hal promosi jabatan. Karyawan yang telah dikembangkan dan ditingkatkan tugasnya, apabila mampu memberikan suatu hasil prestasi kerja maka selayaknya karyawan tersebut memeperoleh promosi dari perusahaan. Pengembangan dan peningkatan yang dilakukan sebaiknya diarahkan pada pengawasan, kepercayaan manajemen kepada karyawan, keeratan hubungan antara manajemen, serta ketepatan dalam hal pengembangan, sehingga kepuasan kerja karyawan akan meningkat.

3) Dimensi variabel lingkungan kerja non fisik yang memiliki nilai korelasi tertinggi adalah dimensi sistem penghargaan. PT Kustodian Sentral Efek Indonesia hendaknya memaksimalkan sistem penghargaan yang ada agar karyawan dapat bekerja dengan motivasi tinggi serta berprestasi dalam mencapai tujuan perusahaan. Pemberian penghargaan kepada karyawan juga dapat menaikkan produktivitas dan mem- pertahankan karyawan berprestasi supaya bertahan diperusahaan. Penghargaan yang diberikan perusahaan kepada karyawan harus sesuai dengan harapan dan ekspektasi karyawan untuk dapat memiliki dampak yang positif bagi, karena jika penghargaan yang disediakan tidak sesuai dengan harapan dan ekspektasi maka dampaknya dapat berlawanan dengan usaha perusahaan untuk meningkatkan produktivitas serta dapat menurunkan kepuasan kerja karyawan.

4) Peneliti yang ingin melakukan penelitian mengenai kepuasan kerja hendaknya menambahkan faktor-faktor lain diluar penelitian ini dalam penelitiannya seperti kompensasi, kondisi kerja, budaya organisasi, dan sebagainya sehingga penelitian selanjutnya mengenai kepuasan kerja akan menghasilkan hasil penelitian yang lebih komprehensif.

\section{DAFTAR PUSTAKA}

Arikunto, S. 2010. Prosedur penelitian : Suatu Pendekatan Praktik. Rineka Cipta. Jakarta.

Asfhar, HS. \& Doosti, M. 2016. Investigating the Impact of Job Satisfaction on Iranian English Teacher's Job Performance. Iranian Journal of Languange Teaching Research. Vol. 4. Issue 1, hal. 97 - 115.

Asvir, N. Ahmad, U. dan Fatima, B. 2011. Promotion: A Predictor of Job Satisfaction A Study of Glass Industry of Lahore (Pakistan). International Journal of Business And Soical Science. Vol. 2, No 16, hal. $301-305$.

Ayu, RS. 2015. Pengaruh Pemberdayaan Karyawan, Promosi Jabatan, dan Lingkungan Terhadap Kepuasan Kerja Serta Dampaknya Terhadap Retensi Karyawan Kajian Pada Region III PT Permata Bank Tbk. Tesis. Pogram Studi Magister Manajemen, Program Pasca Sarjana. Universitas Mercu Buana. Jakarta.

Emmanuel, AO. \& Hassan, Z. 2015. The Effects of Transformational Leadership on Job Satisfaction: A Study on Four and Five Star Hotels in Kuala Lumpur. International Journal of Accounting, Business, and Management. Vol. 1, No 1, hal. 1 - 14.

Fath, RA. 2015. Pengaruh Lingkungan Kerja Non Fisik dan Karakteristik Pekerjaan Terhadap 
Kepuasan Kerja (Studi Pada Karyawan Hotel Bintang Dua di Yogyakarta). Skripsi. Pogram Studi Manajemen, Fakultas Ekonomi. Universitas Negeri Yogyakarta. Yogyakarta.

Fatima B. Ahmad U. \& Asvir N. 2011. Effect of Transformasional Leadership on Employee's Job Satisfaction and Organizational Commitment in Banking Sector of Lahore (Pakistan). International Journal of Business And Soical Science. Vol. 2, No 18, hal. 261 - 267.

Ghozali. 2011. Aplikasi Analisis Multivariate dengan Program IBM SPSS 19. Badan Penerbit Universitas Diponegoro. Semarang.

(2013). Aplikasi Analisis Multivariate dengan Program IBM SPSS 21. Badan Penerbit Universitas Diponegoro. Semarang.

Ghulam, M. Shafiq, R. \& Nadeem, A. 2015. Impact of Work Environment on Teacher's Job Satisfaction A Case Study of Private Business Universities in Pakistan. European Journal of Business and Management, Vol. 7, No 13, hal. 299 - 305.

Handoko, TH. 2014. Manajemen Personalia dan Sumber Daya Manusia. Edisi 2. Yogyakarta.

Hughes, RL. Ginnett, RC. \& Curphy, GJ. 2012. Leadership. Mc Graw Hill Companies Inc. New York.

Indermun, V. \& Bayat, MS. 2013. The Job Satisfaction - Employee Performance Relationship: A Theoritical Perspective. International journal of innovative Research in Management. Vol. 11, Issue 2, hal. 1 - 9.

Jain, R. \& Kaur, S. 2014. Impact of Work Environment on Job Satisfaction, International Journal of Scientific and Research Publications. Vol. 4, Issue 1, hal. $1-8$.

Long, CS, Wan MMY, Tan OK, \& Low HH. 2014. The Impact of Transformational Leadership Style on Job Satisfaction. World Applied Sciences Journal. Vol. 29, No 1, hal. $117-124$.

Luthan, F. 2014. Perilaku Organisasi. ANDI. Yogyakarta.

Luthan, \&Doh,J.2014. Manajemen Internasional - Budaya Strategi, dan Perilaku. Edisi 8. Salemba Empat. Jakarta.

Mangkunegara, AAAP. 2011. Manajemen Sumber Daya manusia Perusahaan. PT Remaja Rosdakarya. Bandung.
Mathis, LR \& Jackson, HJ. 2009. Human Resources Management (Manajemen Sumber Daya Manusia). Edisi Sepuluh. Salemba Empat. Jakarta.

Muhammad, N. \& Akhter, M. 2010. Supervision, Salary, and Opportunities for Promotion as Related to Job Satisfaction. ASA University Review. Vol. 4. No 1, hal. 255 - 261.

Mustapha, N. \& Zakaria, ZC. 2013. The Effect of Promotion Opportunity in Influencing Job Satisfaction among Academics in Higher Public Institutions in Malaysia. International Journal of Academic Research in Business and Social Sciences. Vol. 3, No 3, hal. 20 - 26.

Noe, RA. 2010. Employee Training \& Development. Mc Graw Hill. New York.

Noe, RA. Hollenback JR. Gerhart B. \& Wright PM. 2010. Manajemen Sumber Daya Manusia : Mencapai Keunggulan Bersaing. Salemba Empat. Jakarta.

Northouse. PG. 2013. Kepemimpinan: Teori dan Praktik. Edisi 6. Indeks. Jakarta.

Oyebamiji, FF. Kareem, TS. \& Ayeni GO. 2013. The Impact of Job Satisfaction Performance in a Small And Medium Enterprise in Ibadan, South Western, Nigeria. Interdisciplinary Journal of Contemparary Reseach in Business. Vol. 4, No 11, hal. 509 - 521.

Pongpearchan, P. 2016. Effect of transformational Leadership on Strategic Human Resource Management and Firm Success of Toyota's Dealer in Thailand. Journal of Business and Retail Management Research. Vol. 10, Issue 2, hal. 53 - 63.

Rini, HS. 2013. Career Management Dalam Struktur Organization PT Kustodian Sentral Efek Indonesia. Certified Human Resources Profeasional. Jakarta.

Sedarmayanti. 2011. Membangun dan Mengembangkan Kepemimpinan Serta Meningkatkan Kinerja Untuk Meraih Keberhasilan. Edisi 1. Refika Aditama. Bandung.

Sugiyono. 2014. Metode Penelitian Manajemen. Alfabeta. Bandung. 2014. Metode Penelitian Kualitatif Kuantitatif dan R\&D. Alfabeta. Bandung. 2014. Metode Penelitian Kombinasi (Mixed Methods). Alfabeta. Bandung.

Tio, E. 2014. The Impact of Working Environment Towards Employee Job Satisfaction: A Case Study in PT.X, iBuss Management Journal. 
Vol. 2, No 1, hal. 1 - 5.

Tresna, PW. 2016. The Influence of Transformasional Leadership to Organizational Citizenship Behavior with Job Satisfaction as Mediator Variable (Study About Leadership of the Chairmen at Three University in Tasikmalaya). Review of Integrative Business \& Economics Research. Vol. 5, No 2, hal. $295-303$.

Wursanto. 2009. Dasar-Dasar Ilmu Organisasi. Edisi 2. ANDI. Yogyakarta.

Yukl, G. 2010. Leadership in Organization. Prentice-Hall. New Jersey.

Zahid, N. Aman UK. \& Imran, N. 2015. Impact of Job Promotion and Job Advancement on Job Satisfaction in University of KPK Province of Pakistan. Sciences International (Lahore) Journal, Vol. 27, No 2, hal. 1499 1505. 